\title{
Evaluation of long-term production capacity and prospects of the oil and gas industry of Russian Federation
}

\author{
Nikita Kapustin $^{1,2^{*}}$ and Dmitry Grushevenko ${ }^{1}$ \\ ${ }^{1}$ Energy Research Institute of Russian Academy of Sciences, Nagornaya str. 31/2, Moscow, Russia \\ ${ }^{2}$ Russia Russian State University of Oil and Gas, Leninskiy prospect 65, Moscow, Russia
}

\begin{abstract}
The importance of oil and gas industry for Russia is hard to overestimate. Continued leadership in hydrocarbon production and exports are cornerstones for Russian economic and political prowess as well as energy and social security. The key to sustainability of oil and gas production is, first and foremost, the resource base. In this study the authors attempted to analyze production capacity of the contemporary hydrocarbon production projects, both brownfield and greenfield, using the Hubbert linearization approach. The development of several major greenfields and the successful production maintenance at the developed fields provided Russia with record levels of production, even compared to the period of the USSR and created a potential for further production growth up to 2020. However, by 2025 this potential will be exhausted and only tapping into hard-to-recover reserves and Bazhen formation will be able to slow down the inevitable decline in production. This, however, will largely depend on active domestic development of new production technologies. The situation in the gas industry appears more favorable. Massive reserves of conventional gas, primarily in the Yamal Peninsula, provide the means to increasing annual production to over 1 trillion cubic meters. At the same time, even such a base of new reserves is not capable of completely replacing the phasing out of giant deposits of Nadym-Pur-Taz, which leads to the subsidence of production capacity beyond 2035 and the need to develop new and more complex resources.
\end{abstract}

\section{Introduction}

Extraction and exports of petroleum and natural gas are the key branches of Russian industry and economy, providing up to half of state budget revenues, ensuring energy security and acting as a geopolitical leverage. However as of late the decline in the productivity of giant conventional fields of Western Siberia [1], the increasingly complex geology and geography of promising reserves [2], against the background of economic instability and technological sanctions of Western countries [3] casts doubt on the ability of the country to sustain production.

The cornerstone of hydrocarbon production is, of course, the resource base which, in large part, defines output from the onset of fields' development. Thus, to access the long-term prospects of Russian oil and gas production in this study the authors carried out a projectby-project analysis of the country's hydrocarbon resource base, its changes and challenges, determine production capacity and formulate adaptation strategies to achieve the optimal utilization of these capacities.

\section{Methodology and Data}

The main complication that arises when assessing the production capacity of hydrocarbon extraction projects is scarcity of available data. This is especially true for greenfields; the information is usually limited to launch date and maximum production level, all the while the production lifecycle of an oil or gas field can last decades, while the planned production (or plateau) rarely lasts more than 5-10 years. It should be noted that even for existing fields with a long history of development, the data in most cases is fragmented, and production levels cannot be determined by simple extrapolation.

The common approach to alleviate this issue is the Hubbert linearization method was used as a scientific base for this study, widely implemented by domestic [4; 5] and international [6;7] researchers, modified based on the research of extensive database of Russian fields' production profiles.

The Hubbert linearization is an empirical regularity that assumes the existence of four distinct successive lifecycle stages of each hydrocarbon production project, the boundaries of which are determined by the depletion rate (the ratio of accumulated production to initial recoverable reserves) of initial recoverable reserves (IRR). Each stage is characterized by unique dynamics of the key indicator, to determine the gross production extraction rate (the ratio of oil or gas production to the initial recoverable reserves):

- $\mathrm{I}^{\text {st }}$ stage (from the launch of production to $8-15 \%$ of the IRR depletion) is the initial stage of development demonstrating rapid, almost exponential growth of the

nikita.kapustin@mail.ru 
annual extraction rate to the plateau level;

- II $^{\text {nd }}$ stage (from $8-15$ to $50-60 \%$ of the IRR depletion) - plateau stage of maximum output, characterized by stabilization of extraction rates at 3,5 to $6 \%$ of the IRR;

- III $^{\text {rd }}$ stage (from $50-60$ to $80-85 \%$ of the IRR depletion) - the stage of extraction rate dip to $1-1.5 \%$ of the IRR;

- IV $^{\text {th }}$ stage (over $80 \%$ of IRR depletion) - the final stage of development, characterized by low, gradually declining extraction rates.

Four lifecycle stages can be represented as a graph with IRR depletion on the $\mathrm{X}$ axis and extraction rate on Y (Fig. 1).

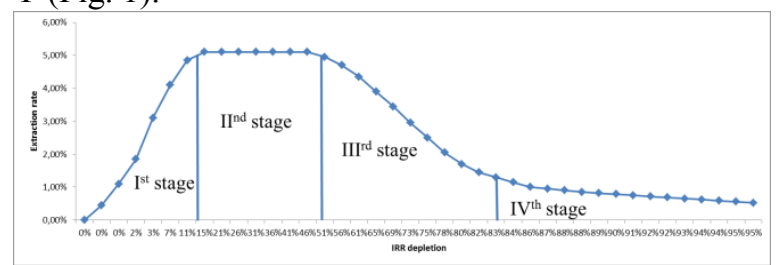

Fig. 1. The dynamics of crude oil production capacity by source (left axis) and average ulifting costs (right axis) up to 2040

To calculate prospective production rates at the field under consideration, only a handful of data is required: the volume of initial and current recoverable reserves; production retrospective (for brownfields) or planned production, the year of launch and reaching the designated production (for greenfields).

Analysis of relative production, accumulated production and initial recoverable reserves, allows determining the lifecycle stage of the field through calculating the extraction rate and reserves depletion rate. Hubbert linearization is applied to build individual profile and trace both retrospective and prospective extraction and production rates. It is worth noting that the accuracy of the production profile will be higher, the greater the amount of retrospective data will be used; however, the information for a single year may be enough for calculations. Prospective (and missing retrospective) production rates are determined by the imposition of theoretical data on the dynamics of the extraction rates at different lifecycle stages, given above with an adjustment to the existing retrospective data. The gross production rates are calculated by the inverse operation: multiplying the volumes of IRR on extraction rate at a given year.

For greenfield projects, a similar algorithm is used, where the key point is the production rate at the second stage of development (the project production rate), relative to which the production profile is drawn.

The database used for the study includes information on the reserves of more than 150 of the largest gas, gas condensate, oil and gas condensate, oil and gas and oil fields of the Russian Federation.

Detailed retrospective data on the dynamics of production and reserves was collected for the 60 largest operating fields and production projects, which provided more than $95 \%$ of annual production in 2017 . Individual production profiles were drawn based on this data.

The outlook on production capacity was carried out under assumption, that all of production projects will be launched according to the announced schedules and will reach the target output, if supported by the resource base. Associate gas and gas condensate were calculated based on the figures for oil and gas production respectively for each individual project, based on the assumption of the immutability of gas and condensate factors over the forecast period.

\section{Results and Discussions}

\subsection{Petroleum production capacity}

The looming resource base depletion has been haunting Russian oil industry since the late 80's. Yet, efficient efforts by oil companies and government allowed Russian liquid hydrocarbon output to reach record highs in 2017, but maintaining this production in the long run is a serious challenge.

In our research we have broken down all of the analyzed production projects into 5 distinct groups:

1 st - conventional brownfields and greenfields mostly situated in West Siberian and Volgo-Ural basins;

2nd - gas condensate as a by-product of the gas industry; 3rd - conventional fields, situated in Russian Eastern Siberia and Far East;

4th - high-cost, low-margin fields, known in Russia as ТРИЗ (rus. Трудноизвлекаемые Запасы - hard-do recover reserves);

5 th - tight oil from Bazhen formation.

Our estimations show that up until 2030 Russia can maintain fairly stable production on the conventional resource base alone. Indeed, several major projects, like Messoyakha and Imilorskiya groups, Russkoye and Roghozynovskoye coupled with expansion of condensate production will be able, to a degree, to offset the decline in brownfield production. But, by 2035 the greenfields themselves are bound to enter late stages of development and more complex resources will have to be introduced. Yet each of them comes with their own set of issues:

Eastern oil basins are still largely unexplored and hold considerable potential, yet, without the large-scale infrastructural development of the region these resources are bound to remain untapped.

The Bazhen formation is a potential source of millions upon millions tons of oil trapped in low-permeability rock. The success of US shale oil prompted optimism for Bazhen oil, however attempts at straightforward adopting American technologies failed and sanctions put a lid on further cooperation. The future of Russian LTO hinges on domestic technological development [8; 9; $10]$.

Last, but not least is the wide range of hard-do recover reserves. Oil reserves may be classified as ТРИЗ based on several factors, including, but not limited to depth of occurrence, reservoir permeability, oil density, geographic location and other. The unifying factor is 
their high production costs that require tax incentives. The combination of production from these sources can help to stabilize production up until 2040. This will come at a price, however. Even with no account for inflation and cost escalation, the average uplifting cost of Russian oil will increase twofold over the forecast period, just due to the exhaustion of cheap oil sources and the need to shift to more expensive ones (Fig. 2).

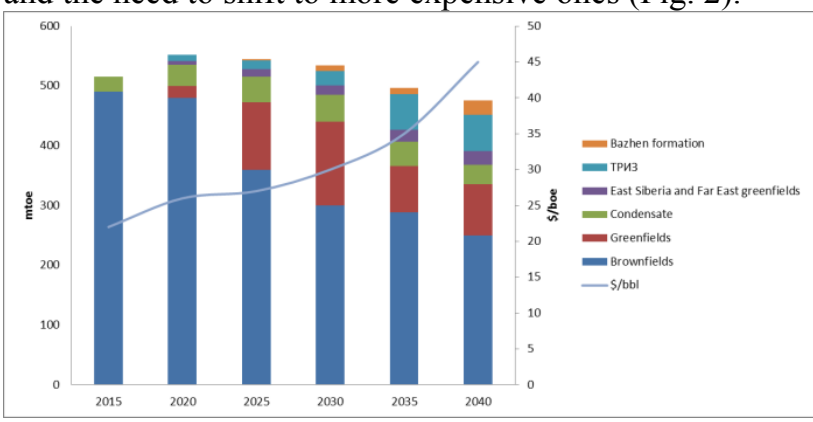

Fig. 2. The dynamics of crude oil production capacity by source (left axis) and average uplifting costs (right axis) up to 2040

\subsection{Natural gas resource base and production potential overview}

The outlook on the Russian gas industry production capacity is shown on the graph below (Fig. 3). Conventional resource base of natural gas in Russia is undoubtly vast, offering potential to increase production over $950 \mathrm{bcm}$ by 2030 .

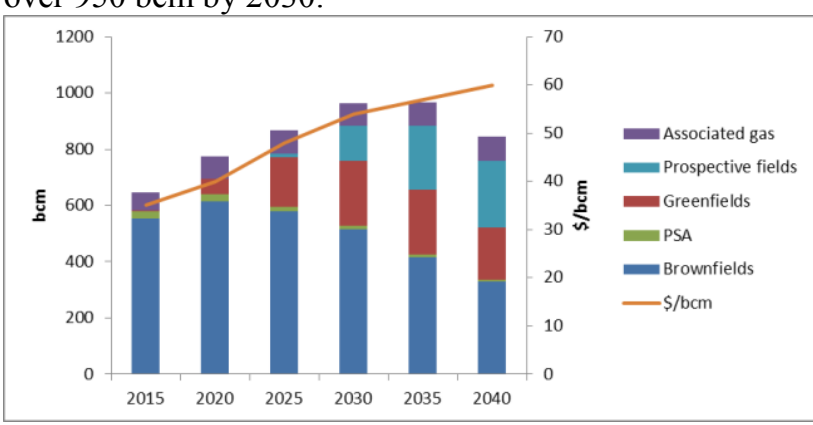

Fig. 3. The dynamics of natural gas production capacity by source (left axis) and average uplifting costs (right axis) up to 2040

As expected, brownfields show a stable decline in production throughout the forecast period. This is primarily due to the depletion of reserves of unique fields: Urengoy, Yamburg, Medvezhye, Zapolyarnoe, which, however, will continue to have a significant impact on the industry until the end of the forecast period providing over 200 billion cubic meters of gas in 2040. The greenfield and prospective (expected to launch beyond 2025) projects have the cumulative production capacity of over $450 \mathrm{bcm}$ reached around 2035. The role of associated petroleum gas (APG) is very significant, providing an average of $10-11 \%$ of production, which explains the efforts of Russian Government to stimulate its rational use.

Yet, by 2040 production spur of the reviewed projects will be exhausted. Moreover, much like the oil industry, gas production will also be forced to produce more expensive gas, resulting in average uplifting costs growing to over $60 \$ / \mathrm{bcm}$ in 2040 compare to around 35 $\$ /$ bcm in 2018.

The distribution of reserves by production regions is also notable. Among the brownfields, Western Siberia dominates, while other regions are represented primarily by large Astrakhan and Orenburg fields, which have restrictions on production volumes (namely the capacities of dedicated gas processing plants). The new projects offer greater diversification, primarily through the involvement of resources in Eastern Siberia and the expansion of offshore production (Fig. 4).
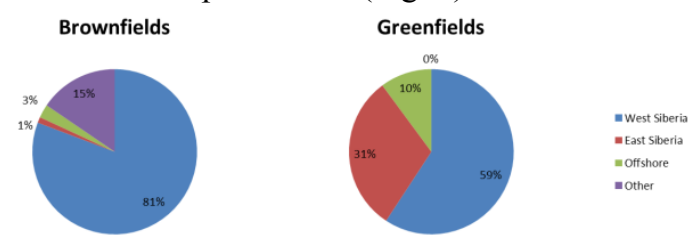

Fig. 4. Distribution of natural gas reserves by production areas

It is worth noting the far Eastern group of major gas fields: Chayandinskoye, Kovyktinskoye, Sobinskoye, Dulis'minskoye. These deposits are capable of producing 70 billion cubic meters of gas by 2025 . However, the realization of production capacity will face infrastructure constraints. The intended capacity of the Amur gas processing plant, planned for launch in 2025, designed specifically for processing multicomponent gas from these fields is only 42 billion cubic meters. Capacity of the export corridor to China is 38 billion cubic meters. Isolated from the Unified Gas Supply System (UGSS) and situated in the region with underdeveloped domestic market, it is solely the export capacity to China that will determine output.

\section{Conclusions}

Despite many years of active production, Russia still possesses considerable resource base of conventional oil and gas. Our calculations show, that up to 2030 the country is sufficiently supplied with resources to maintain high levels of hydrocarbon output, both petroleum and natural gas. It is, however, no reason to rest on laurels, but rather a respite to take actions towards long-term sustainability. This includes tax reforms to incentivize low-margin projects, $R \& D$ stimulation for unconventional oil and gas development. Eastern provinces of Russia have the potential to grow in importance for the industry. It is true for gas (as mentioned above) but also oil industry (Fig. 5). Providing infrastructure and stimulating local markets are ways to go to tap into the new resources. 


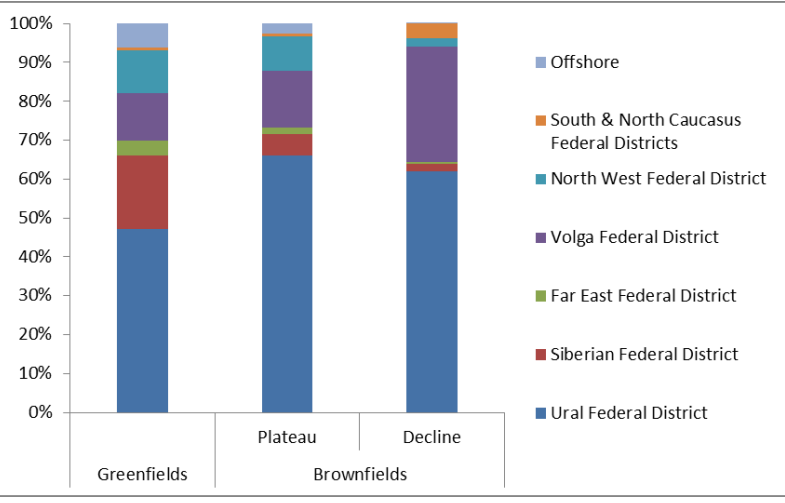

Fig. 5. Distribution of crude oil reserves by federal district

The main point to take away, however, is that both oil and gas will become increasingly expensive to produce, thus limiting companies income, cutting into the budget revenues and threatening to destabilize domestic market. It may be that maintaining maximum production and exports at all costs is a faulty strategy and long-term economic sustainability for Russia lies in diversification and structural reforms.

\section{References}

1. James Henderson, Ekaterina Grushevenko. Russian oil production outlook to 2020. The Oxford Institute for Energy Studies. February 2017.

2. Minenergo. Energy Strategy of Russia up to 2035 project (01.02.2017 edition). Available at: https://minenergo.gov.ru/node/1920 (Accessed: 01.04.19)

3. Mitrova T., Grushevenko E., Malov A. The Future of Oil Production in Russia: Life under Sanctions. SKOLKOVO Energy Centre (SEneC). March 2018.

4. Гавура В.Е. Геология и разработка нефтяных и газонефтяных месторождений. - М.: ВНИИОЭНГ, 1995.

5. Базив В.Ф. Экспертно-аналитическая оценка эффективности систем разработки нефтяных месторождений с заводнением. - М.: ВНИИОЭНГ, 2007 г.

6. Steve H. Mohr, Geoffrey M. Evans. Combined Generalized Hubbert-Bass Model Approach to Include Disruptions When Predicting Future Oil Production. Natural Resources, 2010, 1, 28-33.

7. Efstathios E. Michaelides. A New Model for the Lifetime of Fossil Fuel Resources. Nat Resour Res (2017) 26: 161.

8. Kapustin N., Grushevenko D. Global prospects of unconventional oil in the turbulent market: a long term outlook to 2040, Oil \& Gas Science and Technology Rev. IFP Energies nouvelles 73, 67, 2018.

9. RusEnergy. A Bakken in Siberia: Americans offer a technology for developing Bazhenov formations, The Russian Energy, 2013, March 18.

10. Mitrova T. Can the U.S. Shale Gas and Tight Oil Boom Happen Elsewhere? The Case of Russia, ERI RAS, 2013, November 4-5, New York.
11. Makarov A., Grigoriev L., Mitrova T. (Eds.) (2016). Global and Russian Energy Outlook, ERI RAS - ACFR, Moscow. ISBN 978-5-91438-023-3

12. Henderson J., Grushevenko E. Russian oil production outlook to 2020, The Oxford Institute for Energy Studies, Energy Insight: 3, February, 2017. 